Article

\title{
Screening of Rice Endophytic Biofertilizers with Fungicide Tolerance and Plant Growth-Promoting Characteristics
}

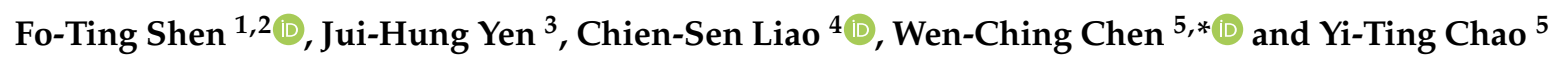 \\ 1 Department of Soil and Environmental Sciences, National Chung-Hsing University, Taichung 40227, Taiwan; \\ ftshen@dragon.nchu.edu.tw \\ 2 Innovation and Development Center of Sustainable Agriculture (IDCSA), National Chung-Hsing University, \\ Taichung 40227, Taiwan \\ 3 Department of Agricultural Chemistry, National Taiwan University, Taipei 10617, Taiwan; sonny@ntu.edu.tw \\ 4 Department of Civil and Ecological Engineering, I-Shou University, Kaohsiung 84001, Taiwan; \\ csliao@isu.edu.tw \\ 5 International Bachelor Program of Agribusiness, National Chung-Hsing University, Taichung 40227, Taiwan; \\ alicechao@nchu.edu.tw \\ * Correspondence: julychen@nchu.edu.tw; Tel.: +886-4-22840849 (ext. 623); Fax: 886-4-22851922
}

Received: 17 January 2019; Accepted: 19 February 2019; Published: 21 February 2019

check for updates

\begin{abstract}
The application of pesticides is unavoidable in conventional agricultural practice. To develop effective biofertilizers, bacterial strains with both pesticide tolerance and plant growth-promoting (PGP) traits were isolated for further testing. Seedlings of rice (Oryza sativa) were planted in soil with 1,5, or 10 times the recommended rates of the fungicides etridiazole, metalaxyl, and tricyclazole. Endophytic bacteria were isolated from roots of rice seedlings. The bacterial $16 \mathrm{~S}$ rDNA sequences and related PGP characteristics including potential nitrogen fixation, phosphorus-solubilizing and indole acetic acid (IAA) production ability were further examined. In all, 17 different strains were obtained from rice seedling roots; five strains with both nitrogen fixation potential and IAA production ability included Rhizobium larrymoorei E2, Bacillus aryabhattai E7, Bacillus aryabhattai MN1, Pseudomonas granadensis T6, and Bacillus fortis T9. Except for T9, all strains could tolerate two or more fungicides. We inoculated rice roots with the endophytic bacteria and all conferred rice growth-promoting ability. Bacillus aryabhattai MN1 was further tested and showed high tryptophan dose-dependent IAA production ability, tolerance towards etridiazole and metalaxyl application and should be considered a potential bacterial biofertilizer.
\end{abstract}

Keywords: endophyte; plant growth promoting; fungicide; indoleacetic acid; Oryza sativa

\section{Introduction}

Rice is the largest crop cultivated in Taiwan and is a major source of food in Asia. To achieve high yield, considerable progress has been made in its cultivation, including breeding, nursery cultivation, fertilizer management and pest control, for one of the most representative crops in the world [1].

Bacterial biofertilizers are plant growth-promoting rhizobacteria (PGPR) applied in the field to promote crop growth and reduce the need for synthetic fertilizers. PGPR promote plant growth in many ways, including nitrogen fixation, phosphorus dissolution, secretion of chelating substances such as siderophores; cyanide and extracellular polysaccharide; and plant hormones such as indole acetic acid (IAA) [2].

Endophytic bacteria are defined as bacteria colonizing the internal tissues of plants (apoplasm or symplasm) without causing symptomatic infections or having negative effects on their host [3]. As compared with many rhizobacteria, endophytes have generally greater beneficial effects [4] and are 
less likely to encounter an extreme change of the soil environment because of the insulation of plants. Thus, to achieve better yield and protection of rice, the use of endophytic rather than rhizobacter biofertilizers, is preferred.

The possibility of inoculating rice endophytic bacteria strains has been studied. Diazotrophic endophyte Azoarcus sp. BH72 is one model species among many that was found capable of colonizing the interior of rice roots [5]. Rice endophyte Burkholderia vietnamensis was inoculated in pots and in the field to raise rice grain production significantly [6]. Stenotrophomonas maltophilia and Ochrobactrum sp. were isolated from rice seeds, and from the result of PCR-DGGE analysis, soil types alter rice endophytic bacterial diversity: the endophytes Pseudomonas oryzihabitans and Rhizobium radiobacter dominated in neutral $\mathrm{pH}$ soil, Enterobacter-like and Dyella ginsengisoli dominated in acid soil, and Stenotrophomonas maltophilia could be found in both soil types [7]. The production of 1-aminocyclopropane-1-caboxylate (ACC) deaminase was found to be a useful trait for elongation and endophytic colonization of rice roots under constant flooded conditions [8]. Therfore, endophytic bacteria could be used as biofertilizers in promoting rice growth and production.

However, to develop effective bacterial biofertilizers, PGP traits and also pesticide tolerance should be confirmed before their application because applying pesticides is inevitable in most agriculture practices [9]. The fungicides etridiazole, metalaxyl, and tricyclazole are recommended for rice leaf blast and rice blight in rice seedling boxes in Taiwan. Etridiazole [5-ethoxy-3(trichloromethyl)-1,2,4-thiadiazole] causes the hydrolysis of cell membrane phospholipids into free fatty acids and lysophosphatides, leading to the lysis of membranes in fungi [10,11]. Metalaxyl [methyl 2-(N-(2-methoxyacetyl)-2,6-dimethylanilino) propanoate] inhibits RNA and protein synthesis in many members of the Peronosporales [12]. Tricyclazole [5-methyl-1,2,4-triazolo[3,4-b] benzothiazole] is a systemic fungicide used to control Pyricularia oryzae (rice blast) in transplanted and direct-seeded rice [13]. Because of its systemic activity, it also reduces damage to roots as seedlings against Pythium spp. seed decay [14].

Fungicide application may have adverse effects on PGP traits in rhizobacteria. Although phosphatesolubilizing Pseudomonas putida isolated from mustard (Brassica compestris) rhizosphere could survive with high concentrations of fungicides hexaconazole, ketazin, metalaxyl, and tebuconazole, PGP attributes such as phosphate-solubilizing and IAA secretion were significantly and dose-dependently inhibited by fungicides at recommended rates [9]. Application of organophosphates on the PGPR Methylobacterium spp. and Bacillus spp., markedly reduced the microbial population, especially Methylobacterium spp. which was completely extinct in soil treated with chlorpyrifos, phorate and dimethoate [15]. The tolerance of 20 bacterial strains isolated from rhizosphere of okra plants with high doses of bifenthrin applied, demonstrated that the growth of most of the strains decreased with increasing pesticide dose [16]. It was reported that etridiazole and metalaxyl adversely affected ammonifying or nitrifying bacteria in soils [11]; therefore, the multiple or alternatively apply of different fungicides such as etridiazole, metalaxyl, and tricyclazole may also impede the functions of the non-target PGPR. The hypothesis of this study was that applying of biofertilizers with pesticide-tolerant ability would maintain their functions and would be capable of promoting the growth of the crops under the pesticides applied.

According to Taiwan's plant protection manual [17], the recommended rates for etridiazole, metalaxyl, and tricyclazole are 6.7, 9.3, and $160.3 \mathrm{mg} / \mathrm{kg}$, respectively in a $60 \times 30 \times 4 \mathrm{~cm}$ rice seedling box. From previous research, the $\mathrm{EC}_{50}$ on Pythium sp. isolated from carrot were 11.1 and $133.3 \mathrm{mg} / \mathrm{L}$ for metalaxyl and etridiazole, respectively [18]. The $\mathrm{EC}_{50}$ for tricyclazole on rice blast Magnaporthe oryzae was $100.41 \mathrm{mg} / \mathrm{L}$ [19]. Tricyclazole, at higher levels $(20-40 \mathrm{mg} / \mathrm{kg})$, reduced the growth and sporulation of the cadmium-tolerant fungi Exophiala pisciphil, but the toxic effects were not observed at a lower concentration, $2.5 \mathrm{mg} / \mathrm{kg}$ [20].

From previous studies, it is important to examine the impact of pesticides during the process of developing biofertilizers in order to make sure the functions of the biofertilizers in the field. This study aims at screening potential endophytic biofertilizers with fungicides tolerance and plant growth-promoting characteristics. 


\section{Materials and Methods}

\subsection{Isolation of the Rice Endophytes}

Following the suggestions from Taiwan's Plant Protection Manual [17], we applied 1, 5, and 10 times the recommended rates of tricyclazole, metalaxyl and etridiazole to soils in plastic trays where rice (Oryza sativa, cultivar Tainan 11) was planted. We also followed the manual's suggestions to apply the fungicides at different periods. Tricyclazole and etridiazole were applied before rice planting, and metalaxyl was applied a week after rice germination. Rice grains were surface-sterilized prior to the test by soaking them in $60^{\circ} \mathrm{C}$ sterilized $\mathrm{H}_{2} \mathrm{O}$ for $10 \mathrm{~min}$, then seeds were soaked in sterilized $\mathrm{H}_{2} \mathrm{O}$ for germination. The soils were from paddy fields in Hualien, with pH 6.7 and texture silt loam. After incubation in the plant growth chamber for 2 weeks at $25^{\circ} \mathrm{C}$, humidity $70 \%$, with $12 \mathrm{~h}$ light: $12 \mathrm{~h}$ dark photoperiod, rice endophytes were isolated.

Rice plants were uprooted from the soil. The shoots and the roots were separated. Roots were soaked in sterilized $\mathrm{H}_{2} \mathrm{O}$ to remove soil particles, then in $70 \%$ ethanol solution for $30 \mathrm{~s}$, rinsed with sterilized $\mathrm{H}_{2} \mathrm{O}$ again and the root surface was cleaned with $3 \%$ sodium hypochlorite solution for $3 \mathrm{~min}$. Roots were washed thoroughly by using sterilized $\mathrm{H}_{2} \mathrm{O}$ several times. The final portion of the sterilized $\mathrm{H}_{2} \mathrm{O}$ washed through the root surface was collected. The water was spread onto a sterilized nutrient broth agar plate to ensure total sterilization of the root surface. A mortar was used to grind roots. Root debris was diluted by using sterilized $\mathrm{H}_{2} \mathrm{O}$ and the suspension was spread onto a sterilized nutrient broth agar plate.

Plates were incubated under $30^{\circ} \mathrm{C}$ for several days after colonies were formed. Colonies with different morphology were isolated and incubated in a new sterilized nutrient broth agar plate, and the purity of the colony was confirmed by using the streak plates method twice.

\subsection{Identification of Bacteria}

DNA was extracted from isolated colonies by using the Exgene DNA Purification Kit (GeneAll Biotechnology). DNA fragments were amplified by using $16 \mathrm{~S}$ rDNA universal primer $27 \mathrm{~F}$ and 1492 R [21] with a polymerase chain reaction (PCR) machine (Biometra T3000). The PCR reaction mixture contained 2x Taq PCR Master Mix (Ginomics BioScience and Technology) and $0.4 \mu \mathrm{M}$ of the primers. The $16 \mathrm{~S}$ rDNA was amplified with $95^{\circ} \mathrm{C}$ denaturing for $5 \mathrm{~min}$, followed by 35 cycles of $94{ }^{\circ} \mathrm{C}$ for $0.25 \mathrm{~min}, 60{ }^{\circ} \mathrm{C}$ for $1.25 \mathrm{~min}, 72{ }^{\circ} \mathrm{C}$ for $1.5 \mathrm{~min}$, and with a final extension at $72{ }^{\circ} \mathrm{C}$ for $5 \mathrm{~min}$. The DNA sequencing was performed with the ABI PRISM 3700 DNA Analyzer (Perkin Elmer Applied Biosystems) by Seeing Biosciences (Taiwan).

\subsection{Phylogenic Tree}

The DNA sequence was searched in the EzTaxon database on 27 July 2017. The phylogenetic tree was constructed by using Mega 7.0 software with the neighbor-joining method and maximum composite likelihood method confirmed by 1000 times of bootstrap analysis. DNA sequences containing gaps and missing data were eliminated [22-25].

\subsection{Indole Acetic Acid (IAA) Production}

IAA production was quantified as described as described by Gordon and Weber (1951) [26] with modification following Brick et al. (1991) [27]. In brief, we inoculated the bacteria strain into $100 \mathrm{~mL}$ Luria Bertani (LB) broth (g/L: tryptone 10; yeast extract 5; $\mathrm{NaCl} 10$ and $\mathrm{pH} 7.5$ ) with $100 \mu \mathrm{g} / \mathrm{mL}$ tryptophan amendment. Three replicates of the culture were agitated under $30^{\circ} \mathrm{C}$ for $24 \mathrm{~h}$. Then, $5 \mathrm{~mL}$ of the culture was centrifuged at $9000 \times \mathrm{g}$ for $15 \mathrm{~min}$. An amount of $1 \mathrm{~mL}$ supernatant was mixed with $1 \mathrm{~mL}$ Salkowsky reagent $\left(2 \% 0.5 \mathrm{M} \mathrm{FeCl}_{3}\right.$ in $35 \%$ perchloric acid) and incubated in the dark for $1 \mathrm{hr}$. The IAA concentration in the supernatant was determined at $540 \mathrm{~nm}$ by using a spectrophotometer (Thermo Scientific ${ }^{\mathrm{TM}}$ GENESYS 10S) against a standard curve. 


\subsection{Potential for Nitrogen-Fixing and Phosphate-Solubilizing Ability}

The culture solution was spread onto a sterilized NFB medium plate [28-30] or a Pikovskaya plate [31]. The bacteria were considered potential nitrogen-fixing bacteria if the color of the plate turned from green to blue after 2 weeks of incubation on an NFB medium plate. The bacteria were considered potential phosphate-solubilizing bacteria if a clear zone around bacterial colony was formed after 7 days of cultivation on a Pikovskaya plate.

\subsection{Fungicides on Bacteria Growth}

Fungicides tricyclazole, metalaxyl and etridiazole were applied at recommended rates following Methods Section 2.1 into NB medium inoculated with the bacteria showing PGP characteristics. The absorbance was measured at $\mathrm{OD}_{600}$ to determine whether bacterial growth was affected by amendment with the fungicides.

\subsection{Endophytic Colonization and the Effect on Rice Growth}

We chose bacteria with both PGP and fungicide tolerance for the following test. Bacteria were inoculated in NB medium solution after colonies exceeded $10^{6}$ colony forming units $/ \mathrm{mL}$. We centrifuged the culture solution and suspended the pellet by using an equal volume of $0.85 \% \mathrm{NaCl}$ solution to become a mixture. Two $\mathrm{mL}$ of the mixture containing different bacteria pellets were then inoculated separately onto 15 rice seedlings (root length $<1 \mathrm{~cm}$ ) in a petri dish with a filter paper. Three replicates of the petri dishes were incubated in a plant growth chamber (conditions resembled those in Methods Section 2.1). The shoot and root length were measured after 4 days of incubation. Prior to the germination, the rice grains were surface-sterilized following the procedure in Methods Section 2.1 before the experiment was conducted.

We tested whether the bacteria were successfully inoculated in the rice roots by also following the isolation procedure from Methods Section 2.1. All strains were successfully isolated from rice roots after inoculation (data not shown).

\subsection{IAA Production in MN1 Culture Medium with Different Tryptophan Concentration}

We amended LB broth with 0, 100, 500, $1000 \mathrm{mg} / \mathrm{L}$ tryptophan and inoculated MN1 in the culture medium in three replicates. After 1,5, and 7 days of cultivation, the supernatant was filtered by using a 0.22- $\mu \mathrm{m}$ membrane. The amount of IAA was quantified following Methods Section 2.9.

\subsection{The Effect of Fungicides on IAA Production by MN1}

We applied the recommended rates of metalaxyl and etridiazole to Bacillus aryabhattai MN1-inoculated LB broth containing $500 \mathrm{mg} / \mathrm{L}$ tryptophan. After 5 days, we determined IAA production by using high-performance liquid chromatography (HPLC) [32] instead of spectrophotometry due to the higher accuracy provided by the HPLC. Chromatographic separation was performed at ambient temperature on a C-18 column (5 $\mu \mathrm{m}, 250-4$, Merck) using a gradient elution. Eluent A consisted of 0.1: 99.9\% $(v / v)$ acetic acid: $\mathrm{H}_{2} \mathrm{O}, \mathrm{pH} 3.8(\mathrm{pH}$ was adjusted by the addition of $1 \mathrm{~mol} / \mathrm{L} \mathrm{KOH}$ ) and eluent $\mathrm{B}$ consisted of $80 \%: 20 \%(v / v)$ acetonitrile: $\mathrm{H}_{2} \mathrm{O}$, the HPLC gradient condition is listed in Table 1. UV wavelength was set to $249 \mathrm{~nm}$. The absorbance wavelength of tricyclazole was close to that for IAA, so we did not test the effect of tricyclazole on IAA production in this experiment. 
Table 1. Gradient program for indole acetic acid (IAA) detection with high-performance liquid chromatography (HPLC).

\begin{tabular}{ccc}
\hline Time (Min) & Eluent A (\%) & Eluent B (\%) \\
\hline & $0.1 \%$ acetic acid $(v / v$, aqueous) & $80: 20$ Acetonitrile: $\mathrm{H}_{2} \mathrm{O}(v / v)$ \\
\hline 0 & 80 & 20 \\
13 & 50 & 50 \\
18 & 0 & 100 \\
22 & 80 & 20 \\
26 & Stop & \\
\hline
\end{tabular}

\subsection{Statistical Analysis}

Data were analyzed by one-way analysis of variance (ANOVA) with SAS v9.4 (SAS Institute Inc., Cary, NC, USA). Post-hoc analysis involved Fisher's least significant difference (LSD) test for significant difference between treatments. $p<0.05$ was considered statistically significant.

\section{Results and Discussion}

\subsection{Endophytes' Isolation with Application of Fungicides}

We isolated bacteria with different morphology from the rice endophytes treated with 1-10 times the recommended rates of tricyclazole, metalaxyl and etridiazole applied in soil: 13 bacterial strains under tricyclazole, 10 with metalaxyl, and 11 under etridiazole were cultured and isolated. We eliminated high-homologous-sequence strains after sequencing. Five endophytic bacteria strains resulted from triclazole treatments, three from metalaxyl treatments and nine from etridiazole treatments (Table 2).

Table 2. The $16 \mathrm{~S}$ rDNA sequence analysis and plant growth-promoting activities of isolated rice endophytes.

\begin{tabular}{|c|c|c|c|c|c|c|}
\hline Treatment $^{\dagger}$ & Strain & Closest Identificaton & $\begin{array}{c}\text { Similarity } \\
(\%)\end{array}$ & $\begin{array}{l}\text { Nitrogen } \\
\text { Fixation }\end{array}$ & $\begin{array}{c}\text { Phosphate } \\
\text { Solubilization }\end{array}$ & $\begin{array}{l}\text { IAA } \ddagger \\
(\mathrm{mg} / \mathrm{L})\end{array}$ \\
\hline $10 \times$ Etridiazole & E1 & Pseudacidovorax intermedius & 100 & + & - & $<1$ \\
\hline $10 \times$ Etridiazole & E2 & Rhizobium larrymoorei & 99.78 & + & - & 4 \\
\hline $10 \times$ Etridiazole & E4 & Sphingomonas aquatilis & 100 & + & + & $<1$ \\
\hline $10 \times$ Etridiazole & E5 & Flavobacterium ginsengiterrae & 97.1 & - & - & $<1$ \\
\hline $10 \times$ Etridiazole & E6 & Brevundimonas vesicularis & 99.63 & - & - & $<1$ \\
\hline $10 \times$ Etridiazole & E7 & Bacillus aryabhattai & 100 & + & - & 7.9 \\
\hline $10 \times$ Etridiazole & E9 & Mycobacterium sphagni & 99.42 & + & + & $<1$ \\
\hline $10 \times$ Etridiazole & E10 & Mycobacterium vanbaalenii & 99.71 & + & - & $<1$ \\
\hline $10 \times$ Etridiazole & EN1 & $\begin{array}{l}\text { Mycobacterium } \\
\text { aromaticivorans }\end{array}$ & 99.06 & + & + & $<1$ \\
\hline $10 \times$ Metalaxyl & M1 & Bacillus sporothermodurans & 98.6 & + & - & $<1$ \\
\hline $5 \times$ Metalaxyl & M7 & Bacillus fortis & 98.17 & - & - & $<1$ \\
\hline $1 \times$ Metalaxyl & MN1 & Bacillus aryabhattai & 100 & + & - & 8.7 \\
\hline $5 \times$ Tricyclazole & T6 & Pseudomonas granadensis & 99.49 & + & + & 2.0 \\
\hline $5 \times$ Tricyclazole & T9 & Bacillus fortis & 98.38 & + & - & 1.1 \\
\hline $5 \times$ Tricyclazole & TN1 & Pseudomonas baetica & 99.57 & + & + & $<1$ \\
\hline $5 \times$ Tricyclazole & TN3 & Pseudomonas plecoglossicida & 99.01 & + & + & $<1$ \\
\hline $1 \times$ Tricyclazole & T3 & Bacillus marisflavi & 99.72 & + & - & $<1$ \\
\hline
\end{tabular}

The phylogenetic tree of the fungicide-tolerant bacterial strains is shown in Figure 1. Three Mycobacerium spp.-Etri N1, Etri 09, and Etri 10-had 100\% consensus rates, and three Pseudomonas spp.-Tric N1, Tric N3 and Tric 06-also had 100\% consensus rate, indicating the robustness of the tree. 


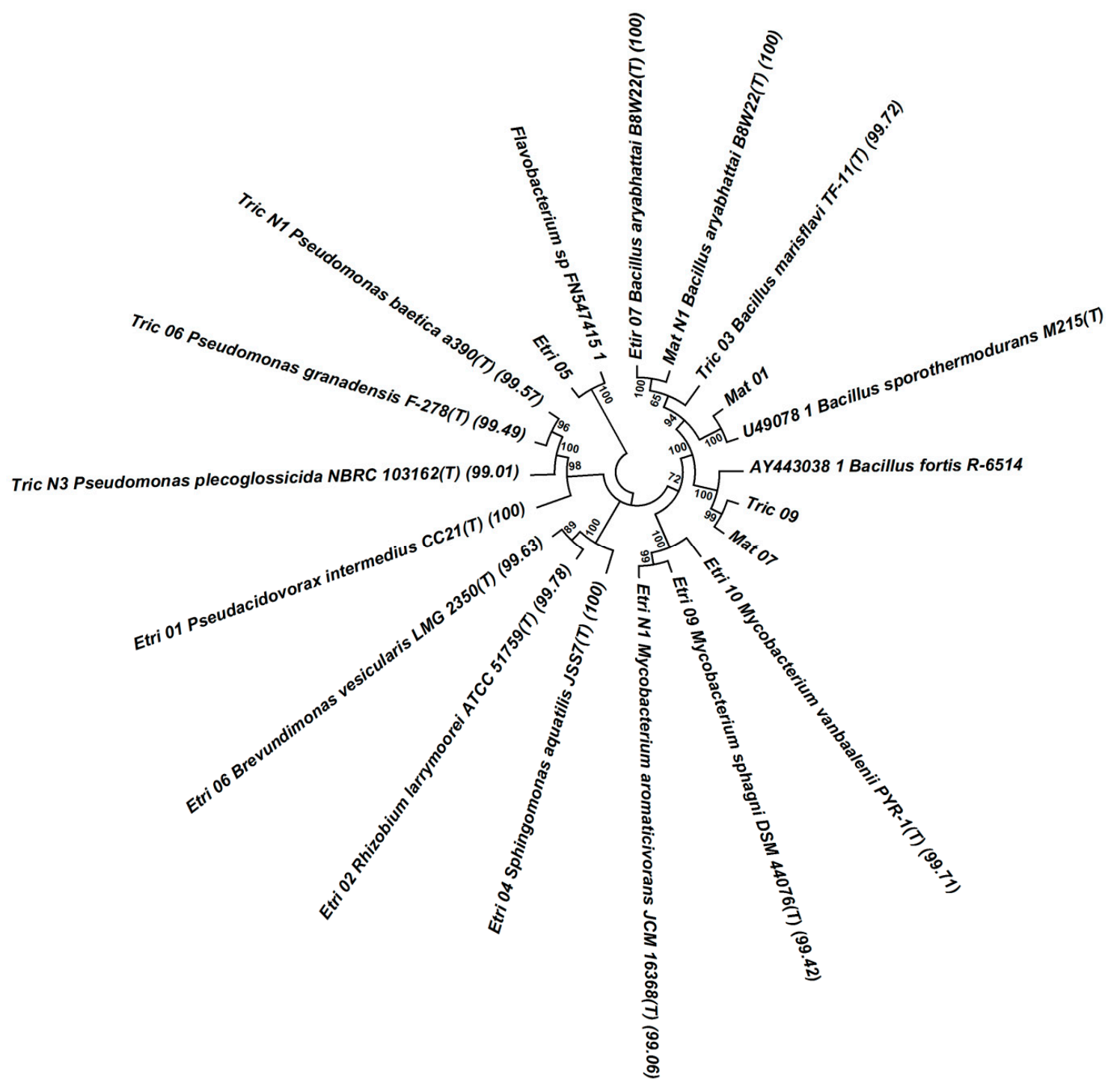

Figure 1. The phylogenetic tree for the isolated endophytes with fungicide tolerance. Numbers shown on branches indicate the percentage of resembling the consensus branch obtained from 1000 times bootstrap analysis. Branches with $<50 \%$ resembling rate were eliminated beforehand.

From Figure 1, the isolates were more abundant and diverse under 10 times the etridiazole recommended dose $(67 \mathrm{mg} / \mathrm{Kg})$ as compared with the other treatments. The isolates included Gram-positive bacteria Mycobacterium aromaticivorans, M. sphagni, M. vanbaalenii, and Bacillus aryabhattai, and Gram-negative Brevundimonas vesicularis, Flavobacterium ginsengiterrae, Pseudacidovorax intermedius, Rhizobium larrymoorei, and Sphingomonas aquatilis. The phenomenon was probably due to the low absorption/distribution rate by the plants or the lower toxicity of etridiazole towards soil biomes. Although etridiazole had been reported to reduce the nitrification rate of ammonium-oxidizing bacteria in soil [33], the nitrogen-fixing bacteria were isolated on high-dose applications in this study (Table 2).

All strains from metalaxyl treatments were Gram-positive Bacillus spp. including B. sporothermodurans, B. fortis, and B. aryabhattai. All three species were reported to be able to survive under adverse environment by producing resistant endospores [34-36].

Strains isolated from tricyclazole treatment were Bacillus spp. and Pseudomonas spp., including B. fortis and B. marisflavi, P. baetica, P. plecoglossicida, and P. granadensis. Among them, P. plecoglossicida was reported to be equipped with bioremediation potential and plant-promoting ability [37,38], and P. granadensis was reported to be isolated from pharmaceutical applied soil [39]. From previous 
research, several strains from the Bacillus and Pseudomonas genera were also found to use insecticide phorate and thiamethoxam as sole carbon source at the same time [40].

We tested the PGP characteristics of these bacteria strains (Table 2). Most of the above-mentioned bacteria strains had one or more PGP characteristics. Fourteen of 17 strains were potential nitrogen-fixing species, including Bacillus spp., Pseudomonas spp., Pseudacidovorax spp., Rhizobium spp., Sphingomonas spp. and Mycobacterium spp. Among them, Pseudomonas intermedius, Brevundimonas vesicularis, Bacillus aryabhattaihas, Bacillus marisflavi, and Pseudomonas baetica were previously reported to have nitrogen-fixing ability [41-44].

Six strains were found with phosphate-solubilizing ability, including Sphingomonas spp., Mycobacterium spp., and Pseudomonas spp. However, the phosphate-solubilizing clear zone was not large enough for SI index calculation.

Five strains had IAA secretion ability, including Rhizobium spp., Bacillus spp. and Pseudomonas spp. The IAA secretion rate was higher for B. aryabhattai MN1 and B. aryabhattai E7 than others and were 8.7 and $7.9 \mathrm{mg} / \mathrm{L}$, respectively. B. aryabhattai, isolated from Crocus sativus rhizosphere, was previously found to produce IAA [45].

Previous research screening for endophytic bacteria with in vitro IAA production potential showed that they could provide a reliable base for selection of effective PGP bacteria [46]. Therefore, we chose R. larrymoorei E2, B. aryabhattai E7, B. aryabhattai MN1, P. granadensis T6 and B. fortis T9, with both nitrogen-fixing and IAA secretion ability for the fungicide tolerance test.

\subsection{Fungicide Tolerance and Rice Inoculation Test}

Table 3 shows the inhibition effect of fungicides on the growth of rice endophytes E2, E7, MN1,T6, T9 and the PGP effect of the endophytes on rice. Under $160 \mathrm{mg} / \mathrm{L}$ tricyclazole, only growth of MN1 was not inhibited. Under $9 \mathrm{mg} / \mathrm{L}$ metalaxyl, the growth of E2, E7, MN1, T6 and T9 was not significantly inhibited, whereas under $7 \mathrm{mg} / \mathrm{L}$ etridiazole, only the growth of T9 was significantly inhibited. The 3 bacterial strains E2, E7, and T6 were able to tolerate etridiazole and metalaxyl fungicides, whereas only MN1 was able to tolerate all tested fungicides. As a result, we tested the rice inoculation effect of E2, E7, MN1, and T6.

Table 3. The growth of potential rice endophytic biofertilizers with fungicide amendment and their effect on rice germination.

\begin{tabular}{|c|c|c|c|c|c|c|}
\hline \multirow[b]{2}{*}{ Bacterial Strain } & \multicolumn{4}{|c|}{ Fungicide Inhibition } & \multicolumn{2}{|c|}{ Inoculation Test } \\
\hline & $\begin{array}{c}\text { Etridiazole } \\
7 \mathrm{mg} / \mathrm{Kg}\end{array}$ & $\begin{array}{l}\text { Metalaxy } \\
19 \mathrm{mg} / \mathrm{Kg}\end{array}$ & $\begin{array}{l}\text { Tricyclazole } \\
160 \mathrm{mg} / \mathrm{Kg}\end{array}$ & $\begin{array}{l}\text { Fungicides } \\
\text { Mixture }\end{array}$ & $\begin{array}{c}\text { Shoots Growth } \\
\text { Promoting }\end{array}$ & $\begin{array}{c}\text { Roots Growth } \\
\text { Promoting }\end{array}$ \\
\hline Rhizobium larrymoorei E2 & - & - & + & + & + & + \\
\hline Bacillus aryabhattai E7 & - & - & + & $\mathrm{N} / \mathrm{A}$ & $=$ & + \\
\hline Bacillus aryabhattai $\mathrm{MN} 1$ & - & - & - & - & $=$ & + \\
\hline Pseudomonas granadensis T6 & - & - & + & $\mathrm{N} / \mathrm{A}$ & + & + \\
\hline Bacillus fortis T9 & + & - & $\mathrm{N} / \mathrm{A}$ & $\mathrm{N} / \mathrm{A}$ & $\mathrm{N} / \mathrm{A}$ & $\mathrm{N} / \mathrm{A}$ \\
\hline
\end{tabular}

+: bacteria growth inhibited by fungicide or seedling growth promotion observed; - : bacteria growth not inhibited by fungicide, or no seedling growth promotion observed; =: not significantly different from the control; "N/A": the experiments were not conducted.

We combined two batches of experiments of inoculating endophytes on the growth of rice (Table 3 ). The average root length of E7 and MN1 was 26.8 and $31.2 \mathrm{~mm}$, both significantly longer than that of the control $(15.9 \mathrm{~mm})$. The average shoot length of E7 and MN1 was 9.2 and $10.2 \mathrm{~mm}$, although higher shoot lengths were observed, it was not significantly different from the control $(7.9 \mathrm{~mm})$ under $95 \%$ confidence level.

The average root lengths with E2 and T6 treatments were 40.3 and $39.2 \mathrm{~mm}$, both significantly longer than the control $(20.2 \mathrm{~mm})$. The average shoot lengths with E2 and T6 treatments were 16.2 and $14.4 \mathrm{~mm}$, also both significantly longer than the control $(9.9 \mathrm{~mm})$. We isolated the endophytes from the rice seedling and verified the successful inoculation (data not shown), thus assuming that the rice growth promotion was contributed by the inoculation of the endophytes E2, E7, MN1 and T6. 
The above tests demonstrated that strain MN1 showed the highest IAA production rates as well as multiple plant growth promoting and fungicide tolerance ability; we therefore examine the growth curve, the tryptophan dose-dependent IAA production rates, and the fungicides' amendment effect on IAA production of MN1 in latter experiments.

\subsection{The Growth Curve of MN1 under Fungicides Application}

The MN1 culture medium was amended with a mixture of the recommended rates of the three fungicides. The fungicides' mixture only slightly retarded the growth of MN1 within $35 \mathrm{~h}$ of incubation (Figure 2); however, after $35 \mathrm{~h}$, the population of MN1 was slightly augmented with the amendment. From previous studies, the application of metalaxyl (both soil and foliar applied) and tricyclazole (foliar applied) at field-recommended rates did not affect the structure and diversity of bacteria and fungi communities [47,48]. Etridiazole at $100 \mathrm{mg} / \mathrm{L}$ application (approximately 14 times the recommended rate) was apparently fatal to ammonium-oxidizing bacteria [33]. In our study, the growth of MN1 was slightly augmented with the fungicides mixture amendment, making it among one of the possible bacterial members capable of utilizing or co-metabolizing the fungicides. From a previous study, one $B$. arybhattai strain isolated from rice rhizospheres was found to be equipped with arsenic absorption and accumulation abilities [49]. However, further analysis still needed to verify its fungicide utilizing ability.

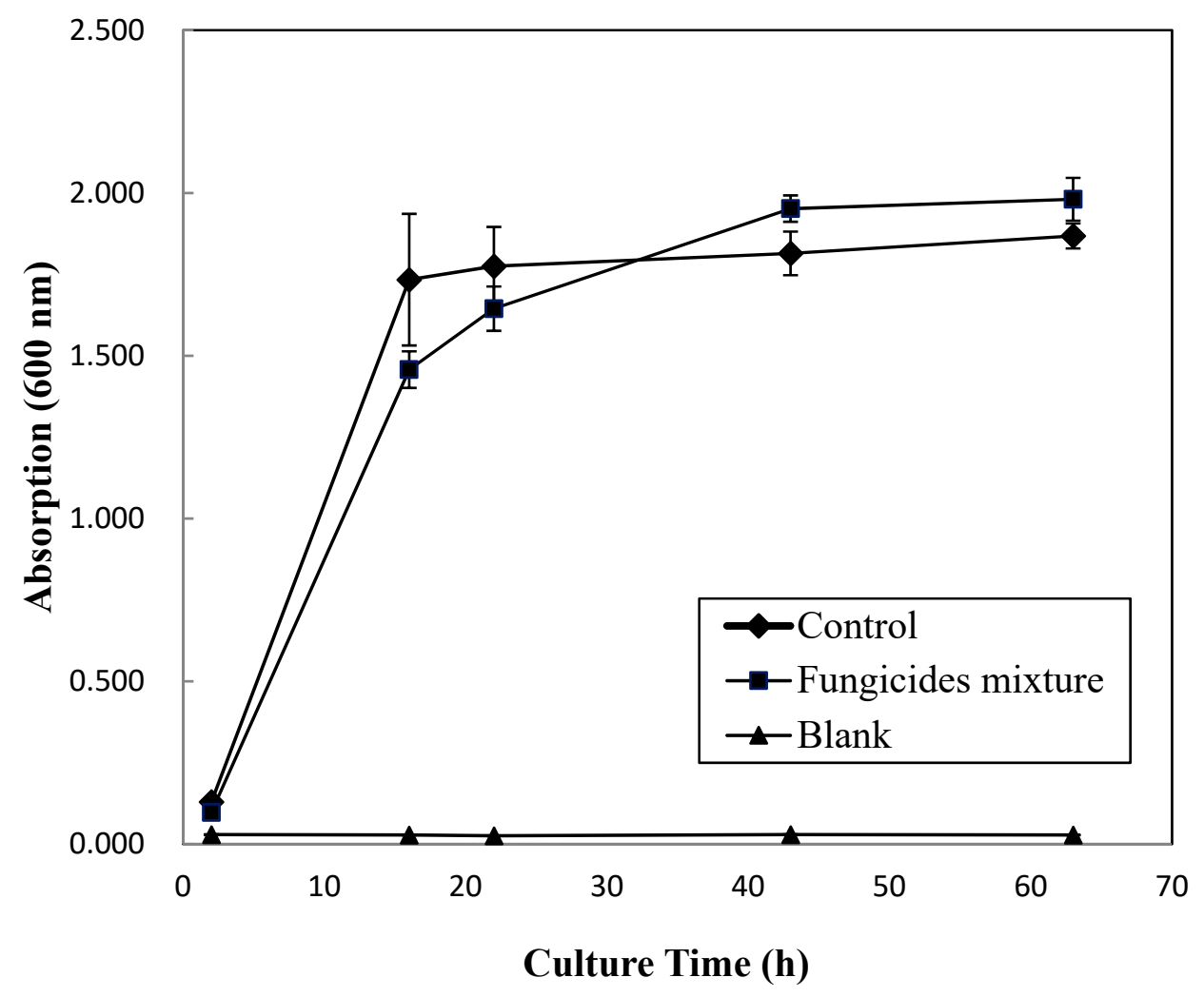

Figure 2. Bacterial growth curve of Bacillus aryabhattai MN1 amended with the recommended dose of fungicides mixture.

\subsection{Tryptophan Dose-Dependent IAA Production Rates of MN1}

Figure 3 shows the IAA-production ability of MN1 with different concentrations of L-tryptophan amendment. After seven days of inoculation, the IAA concentrations in the supernatant with 100, 500 , and $1000 \mathrm{mg} / \mathrm{L}$ tryptophan treatments were $34.2 \pm 5.7,79.7 \pm 3.4$, and $101.7 \pm 12.0 \mathrm{mg} / \mathrm{L}$, respectively. The IAA production ability of MN1 increased with increasing amount of tryptophan amendment. Since the concentrations of tryptophan did not significantly alter the growth of MN1 (data not shown), we assumed that the IAA production rate of MN1 species increased with increasing 
concentration of tryptophan. Similar findings were reported previously [50]: Higher concentrations of tryptophan amendment were previously reported to increase the IAA production rates of Azotobacter spp., fluorescent Pseudomonas spp., and Enterobacter spp. I-3. However, if considering the IAA production rate from unit tryptophan amended at day seven, it was $18.6 \%$ for $500 \mathrm{mg} / \mathrm{L}$ tryptophan applied and $11.9 \%$ for $1000 \mathrm{mg} / \mathrm{L}$ tryptophan.

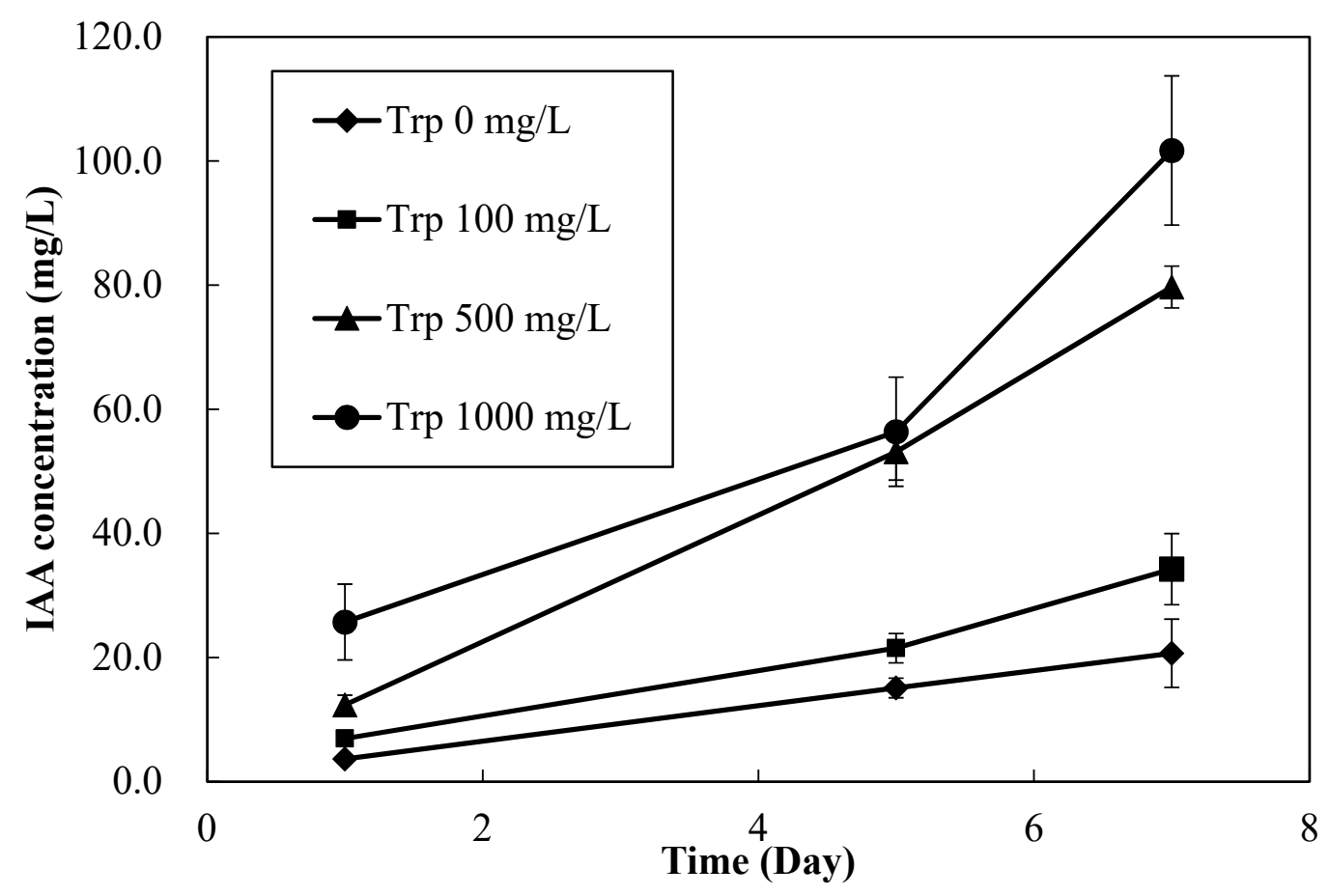

Figure 3. Indole acetic acid (IAA) production in MN1 culture medium with different tryptophan concentrations.

No tryptophan amendment of MN1 produced $3.6 \pm 0.6,15.1 \pm 1.6$, and $20.7 \pm 5.5 \mathrm{mg} / \mathrm{L} \mathrm{IAA}$ at days 1, 5 and 7, MN1, respectively (Figure 3), showing the reasonable assumption that NB broth should contain trace amounts of tryptophan, although relevant tests should be conducted.

The corresponding IAA production by MN1 also showed that MN1 may benefit different plant species by various concentrations of tryptophan amendment, because for each specific plant or even each plant cultivar, there should be a suitable PGP exogenous IAA concentration produced by MN1 with different concentrations of tryptophan applied for future biofertilizer application.

\subsection{Effect of Fungicides on IAA Production of MN1}

We inoculated MN1 in LB culture medium containing $500 \mathrm{mg} / \mathrm{L}$ tryptophan and etridiazole and metalaxyl (Figure 4). We examined IAA production only with $500 \mathrm{mg} / \mathrm{L}$ tryptophan because this conferred the highest growth rate per unit of tryptophan applied. Data for tricyclazole amended are also not shown because under the current HPLC analytic condition, the peaks for IAA and tricyclazole overlapped. 


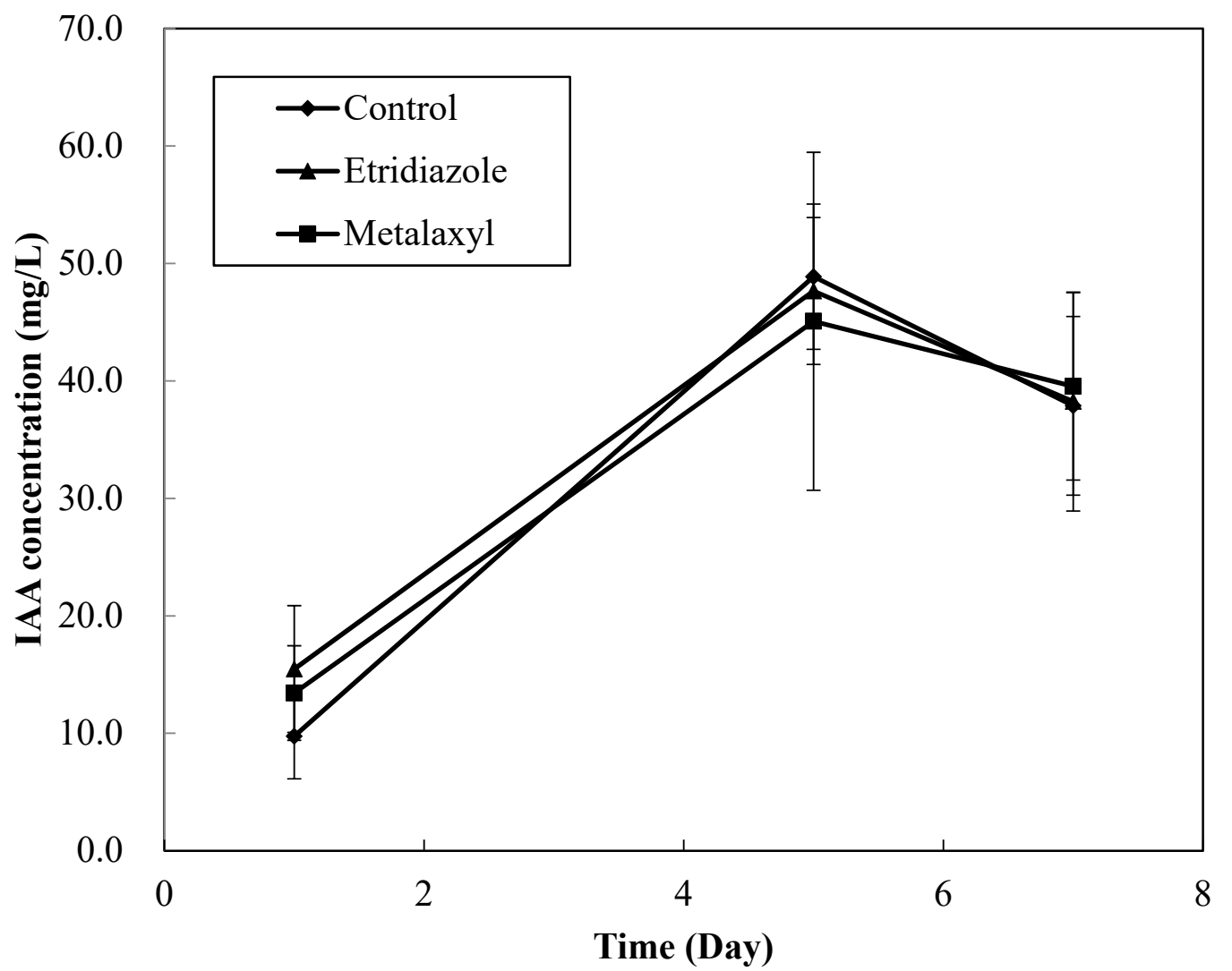

Figure 4. IAA production of Bacillus aryabhattai MN1 under fungicide treatments.

The IAA production of MN1 with control, etridiazole and metalaxyl treatments after 1 day of cultivation were 9.8, 15.5 and $13.4 \mathrm{mg} / \mathrm{L}$, respectively. Higher IAA production rates were observed at day 5 , which were $48.9,47.7$, and $45.1 \mathrm{mg} / \mathrm{L}$, respectively. Although we observed varied IAA production with both fungicide treatments, we found no significant differences at the $95 \%$ confidence level. Thus, we assumed that the fungicides applied had no significant effect on IAA production by MN1.

From previous research, a specific $B$. arybhattai strain isolated from grapevine rhizospheres was considered a potential biofertilizer because it showed various PGP abilities such as nitrogen fixation and the production of IAA, siderophores, 1-aminocyclopropane-1-carboxylate (ACC) deaminase, chitinase, and protease [51]. Another B. arybhattai strain SanPS1 also isolated from soil showed chlorpyrifos and malathion degradation ability [52]. Being among one of the potential bioremediation members as well, it was reported that one B. arybhattai strain isolated from rice rhizospheres was equipped with arsenic absorption and accumulation abilities [49]. The above findings and our research together show that B. arybhattai has diverse functions in various applications.

\section{Conclusions}

From the above experiments, the bacterial strain Bacillus arybhattai MN1 proved to have nitrogen-fixing and IAA-production abilities. With application of the fungicides metalaxyl and etridiazole, the IAA production ability was not adversely affected. Previous results showed that B. arybhattai has diverse functions in various applications, but from our findings, B. arybhattai MN1was the first rice endophyte reported to possess PGP characteristics under multiple fungicides applied, and can promote the growth of rice seedlings. As compared with the isolates from the plant rhizosphere, bacterial endophytes have an advantage because living within a plant's tissues represents an opportunity to always be in contact with plant cells and, therefore, more readily exerts a direct beneficial effect [53]. Thus, in accordance with our hypothesis that applying biofertilizers 
with pesticide-tolerant ability would maintain their functions and would be capable of promoting the growth of the crops under the pesticides applied, B. arybhattai MN1 should be a potential endophytic biofertilizer with fungicide tolerance ability and suitable for application in conventional rice seedling boxes.

Author Contributions: Conceptualization, F.-T.S. and W.-C.C.; Data curation, J.-H.Y. and Y.-T.C.; Formal analysis, J.-H.Y., W.-C.C. and Y.-T.C.; Funding acquisition, W.-C.C.; Investigation, Y.-T.C.; Methodology, F.-T.S., W.-C.C. and Y.-T.C.; Project administration, W.-C.C.; Resources, J.-H.Y. and C.-S.L.; Supervision, W.-C.C.; Validation, F.-T.S., W.-C.C. and Y.-T.C.; Writing-original draft, W.-C.C. and Y.-T.C.; Writing-review and editing, C.-S.L. and W.-C.C.

Acknowledgments: This research work was kindly supported by grants from the Ministry of Science and Technology (105-2313-B-005-005-) and in part by the Ministry of Education, Taiwan, R.O.C. under the Higher Education Sprout Project.

Conflicts of Interest: The authors submitted the MN1 bacteria patent application in Taiwan on 22 June 2018.

\section{References}

1. Peng, S.; Tang, Q.; Zou, Y. Current Status and Challenges of Rice Production in China. Plant Prod. Sci. 2009, 12, 3-8. [CrossRef]

2. Beneduzi, A.; Ambrosini, A.; Passaglia, L.M. Plant growth-promoting rhizobacteria (PGPR): Their potential as antagonists and biocontrol agents. Genet. Mol. Biol. 2012, 35, 1044-1051. [CrossRef] [PubMed]

3. Schulz, B.; Boyle, C. The endophytic continuum. Mycol. Res. 2005, 109, 661-687. [CrossRef] [PubMed]

4. Pillay, V.K.; Nowak, J. Inoculum density, temperature, and genotype effects on in vitro growth promotion and epiphytic and endophytic colonization of tomato (Lycopersicon esculentum L.) seedlings inoculated with a pseudomonad bacterium. Can. J. Microbiol. 1997, 43, 354-361. [CrossRef]

5. Hurek, T.; Reinhold-Hurek, B. Azoarcus sp. strain BH72 as a model for nitrogen-fixing grass endophytes. J. Biotechnol. 2003, 106, 169-178. [CrossRef] [PubMed]

6. Govindarajan, M.; Balandreau, J.; Kwon, S.W.; Weon, H.Y.; Lakshminarasimhan, C. Effects of the inoculation of Burkholderia vietnamensis and related endophytic diazotrophic bacteria on grain yield of rice. Microb. Ecol. 2008, 55, 21-37. [CrossRef]

7. Hardoim, P.R.; Hardoim, C.C.P.; van Overbeek, L.S.; van Elsas, J.D. Dynamics of seed-borne rice endophytes on early plant growth stages. PLoS ONE 2012, 7, e30438. [CrossRef]

8. Etesami, H.; Hosseini, H.M.; Alikhani, H.A. Bacterial biosynthesis of 1-aminocyclopropane-1-caboxylate (ACC) deaminase, a useful trait to elongation and endophytic colonization of the roots of rice under constant flooded conditions. Physiol. Mol. Biol. Plants 2014, 20, 425-434. [CrossRef]

9. Ahemad, M.; Khan, M.S. Effect of fungicides on plant growth promoting activities of phosphate solubilizing Pseudomonas putida isolated from mustard (Brassica compestris) rhizosphere. Chemosphere 2012, 86, 945-950. [CrossRef]

10. Radzuhn, B.; Lyr, H. On the mode of action of the fungicide etridiazole. Pestic. Biochem. Physiol. 1984, 22, 14-23. [CrossRef]

11. Yang, C.; Hame, C.; Vujanovic, V.; Gan, Y. Fungicide: Modes of action and possible impact on nontarget microorganisms. ISRN Ecol. 2011, 2011, 1-8. [CrossRef]

12. Fisher, D.J.; Hayes, A.L. Mode of action of the systemic fungicides furalaxyl, metalaxyl, and ofurace. Pestic. Sci. 1982, 13, 330-339. [CrossRef]

13. Krieger, M.S.; Cook, W.L.; Kennard, L.M. Extraction of tricyclazole from soil and sediment with subcritical water. J. Agric. Food Chem. 2000, 48, 2178-2183. [CrossRef] [PubMed]

14. Hwang, S.F.; Gossen, B.D.; Chang, K.F.; Turnbull, G.D.; Howard, R.J. Effect of seed damage and metalaxyl seed treatment on pythium seedling blight and seed yield of field pea. Can. J. Plant Sci. 2001, 81, 509-517. [CrossRef]

15. Sultan, N.S.; Raipat, B.S.; Sinha, M.P. Survival of plant growth promoting rhizobacteria (PGPR) in soil under pesticide stress. ISESCO J. Sci. Technol. 2013, 9, 82-88.

16. Najam-ul-Sehar Ahmad, M.; Akhtar, M.F.Z.; Jamil, M.; Latif, M.; Ahmad, I. Pesticide tolerant plant growth promoting rhizobacteria isolated from rhizosphere of okra. Soil Environ. 2015, 34, 111-118.

17. Council of Agriculture Executive Yuan, R.O.C. (Taiwan). Plant Protection Manual. 2018. Available online: https:/ / otserv2.tactri.gov.tw/ppm/ (accessed on 15 November 2018). 
18. Martinez, C.; Levesque, C.A.; Belanger, R.R.; Tweddell, R.J. Evaluation of fungicides for the control of carrot cavity spot. Pest Manag. Sci. 2005, 61,767-771. [CrossRef] [PubMed]

19. Kunova, A.; Pizzatti, C.; Cortesi, P. Impact of tricyclazole and azoxystrobin on growth, sporulation and secondary infection of the rice blast fungus, Magnaporthe oryzae. Pest Manag. Sci. 2013, 69, 278-284. [CrossRef] [PubMed]

20. Zhan, F.; He, Y.; Yang, Y.; Li, Y.; Li, T.; Zhao, Z. Effects of tricyclazole on cadmium tolerance and accumulation characteristics of a dark septate endophyte (DSE), Exophiala pisciphila. Bull. Environ. Contam. Toxicol. 2016, 96, 235-241. [CrossRef] [PubMed]

21. Lane, D.J. 16S/23S rRNA sequencing. In Nucleic Acid Techniques in Bacterial Systematics; Stackebrandt, E., Goodfellow, M., Eds.; John Wiley and Sons: New York, NY, USA, 1991; pp. 115-175.

22. Felsenstein, J. Confidence-limits on phylogenies: An approach using the bootstrap. Evolution 1985, 39, 783-791. [CrossRef] [PubMed]

23. Kumar, S.; Stecher, G.; Tamura, K. MEGA7: Molecular evolutionary genetics analysis version 7.0 for bigger datasets. Mol. Biol. Evol. 2016, 33, 1870-1874. [CrossRef]

24. Saitou, N.; Nei, M. The Neighbor-joining method: A new method for reconstructing phylogenetic trees. Mol. Biol. Evol. 1987, 4, 406-425. [PubMed]

25. Tamura, K.; Nei, M.; Kumar, S. Prospects for inferring very large phylogenies by using the neighbor-joining method. Proc. Natl. Acad. Sci. USA 2004, 101, 11030-11035. [CrossRef] [PubMed]

26. Gordon, S.; Weber, R.P. The colorimetric estimation of IAA. Plant Physiol. 1951, 26, 192-195. [CrossRef]

27. Brick, J.M.; Bostock, R.M.; Silversone, S.E. Rapid in situ assay for indole acetic acid production by bacteria immobilized on nitrocellulose membrane. Appl. Environ. Microbiol. 1991, 57, 535-538.

28. Eckford, R.; Cook, F.D.; Saul, D.; Aislabie, J.; Foght, J. Free-living heterotrophic nitrogen-fixing bacteria isolated from fuel-contaminated Antarctic soils. Appl. Environ. Microbiol. 2012, 68, 5181-5185. [CrossRef]

29. Ladha, J.K.; Barraquio, W.L.; Watanabe, I. Isolation and identification of nitrogen fixing Enterobacter cloacae and Klebsiella planticola associated with rice plants. Can. J. Microbiol. 1983, 29, 1301-1308. [CrossRef]

30. Colnaghi, R.; Green, A.; He, L.; Rudnick, P.; Kennedy, C. Strategies for increased ammonium production in free-living or plant associated nitrogen-fixing bacteria. Plant Soil 1997, 194, 145-154. [CrossRef]

31. Pikovskaya, R.I. Mobilization of phosphorus in soil in connection with vital activity of some microbial species. Microbiologiya 1948, 17, 362-370.

32. Szkop, M.; Bielawski, W. A simple method for simultaneous RP-HPLC determination of indolic compounds related to bacterial biosynthesis of indole-3-acetic acid. Antonie Van Leeuwenhoek 2013, 103, 683-691. [CrossRef] [PubMed]

33. Rodgers, G.A.; Ashworth, J. Bacteriostatic action of nitrification inhibitors. Can. J. Microbiol. 1982, 28, $1093-1100$. [CrossRef]

34. Scheldeman, P.; Rodríguez-Díaz, M.; Goris, J.; Pil, A.; De Clerck, E.; Herman, L.; De Vos, P.; Logan, N.A.; Heyndrickx, M. Bacillus farraginis sp. nov., Bacillus fortis sp. nov. and Bacillus fordii sp. nov., isolated at dairy farms. Int. J. Syst. Evol. Microbiol. 2004, 54, 1355-1364. [CrossRef]

35. Shivaji, S.; Chaturvedi, P.; Begum, Z.; Pindi, P.K.; Manorama, R.; Padmanaban, D.A.; Shouche, Y.S.; Pawar, S.; Vaishampayan, P.; Dutt, C.B.; et al. Janibacter hoylei sp. nov., Bacillus isronensis sp. nov. and Bacillus aryabhattai sp. nov., isolated from cryotubes used for collecting air from the upper atmosphere. Int. J. Syst. Evol. Microbiol. 2009, 59, 2977-2986. [CrossRef]

36. Silva, M.P.; Pereira, C.A.; Junqueira, J.C.; Jorge, A.O.C. Methods of destroying bacterial spores. In Microbial Pathogens and Strategies for Combating Them: Science, Technology and Education; Méndez-Vilas, A., Ed.; Formatex Research Center: Badajoz, Spain, 2013; pp. 490-496.

37. Boricha, H.; Fulekar, M.H. Pseudomonas plecoglossicida as a novel organism for the bioremediation of cypermethrin. Biol. Med. 2009, 1, 1-10.

38. Rahmoune, B.; Morsli, A.; Khelifi-Slaoui, M.; Khelifi, L.; Strueh, A.; Erban, A.; Kopka, J.; Prell, J.; van Dongen, J.T. Isolation and characterization of three new PGPR and their effects on the growth of Arabidopsis and Datura plants. J. Plant Interact. 2017, 12, 1-6. [CrossRef]

39. Pascual, J.; García-López, M.; Bills, G.F.; Genilloud, O. Pseudomonas granadensis sp. nov., a new bacterial species isolated from the Tejeda, Almijara and Alhama Natural Park, Granada, Spain. Int. J. Syst. Evol. Microbiol. 2015, 65, 625-632. [CrossRef] 
40. Rana, S.; Jindal, V.; Mandal, K.; Kaur, G.; Gupta, V.K. Thiamethoxam degradation by Pseudomonas and Bacillus strains isolated from agricultural soils. Environ. Monit. Assess. 2015, 187, 300. [CrossRef]

41. Kämpfer, P.; Thummes, K.; Chu, H.I.; Tan, C.C.; Arun, A.B.; Chen, W.M.; Lai, W.A.; Shen, F.T.; Rekha, P.D.; Young, C.C. Pseudacidovorax intermedius gen. nov., sp. nov., a novel nitrogen-fixing betaproteobacterium isolated from soil. Int. J. Syst. Evol. Microbiol. 2008, 58, 491-495. [CrossRef]

42. Liaqat, F.; Eltem, R. Identification and characterization of endophytic bacteria isolated from in vitro cultures of peach and pear rootstocks. 3 Biotech 2016, 6, 120. [CrossRef]

43. Ding, Y.; Wang, J.; Liu, Y.; Chen, S. Isolation and identification of nitrogen-fixing bacilli from plant rhizospheres in Beijing region. J. Appl. Microbiol. 2005, 99, 1271-1281. [CrossRef]

44. Nongkhlaw, F.M.; Joshi, S.R. Epiphytic and endophytic bacteria that promote growth of ethnomedicinal plants in the subtropical forests of Meghalaya, India. Rev. Biol. Trop. 2014, 62, 1295-1308. [CrossRef]

45. Ambardar, S.; Vakhlu, J. Plant growth promoting bacteria from Crocus sativus rhizosphere. World J. Microbiol. Biotechnol. 2013, 29, 2271-2279. [CrossRef]

46. Etesami, H.; Alikhani, H.A.; Hosseini, H.M. Indole-3-acetic acid (IAA) production trait, a useful screening to select endophytic and rhizosphere competent bacteria for rice growth promoting agents. MethodsX 2015, 2, 72-78. [CrossRef]

47. García-Jaramillo, M.; Redondo-Gómez, S.; Barcia-Piedras, J.M.; Aguilar, M.; Jurado, V.; Hermosín, M.C.; Cox, L. Dissipation and effects of tricyclazole on soil microbial communities and rice growth as affected by amendment with alperujo compost. Sci. Total Environ. 2016, 550, 637-644. [CrossRef]

48. Moulas, C.; Petsoulas, C.; Rousidou, K.; Perruchon, C.; Karas, P.; Karpouzas, D.G. Effects of systemic pesticides imidacloprid and metalaxyl on the phyllosphere of pepper plants. Biomed. Res. Int. 2013, 2013, 969750. [CrossRef]

49. Singh, N.; Gupta, S.; Marwa, N.; Pandey, V.; Verma, P.C.; Rathaur, S.; Singh, N. Arsenic mediated modifications in Bacillus aryabhattai and their biotechnological applications for arsenic bioremediation. Chemosphere 2016, 164, 524-534. [CrossRef]

50. Ahmad, F.; Ahmad, I.; Khan, M.S. Indole acetic acid production by the indigenous isolates of Azotobacter and fluorescent Pseudomonas in the presence and absence of tryptophan. Turk. J. Biol. 2005, 29, 29-34.

51. Liu, M.; Liu, X.; Cheng, B.S.; Ma, X.L.; Lyu, X.T.; Zhao, X.F.; Ju, Y.L.; Min, Z.; Fang, Y.L. Selection and evaluation of phosphate-solubilizing bacteria from grapevine rhizospheres for use as biofertilizers. Span. J. Agric. Res. 2016, 14, e1106. [CrossRef]

52. Pailan, S.; Gupta, D.; Apte, S.; Krishnamurthi, S.; Saha, P. Degradation of organophosphate insecticide by a novel Bacillus aryabhattai strain SanPS1, isolated from soil of agricultural field in Burdwan, West Bengal, India. Int. Biodeterior. Biodegrad. 2015, 103, 191-195. [CrossRef]

53. Santoyo, G.; Moreno-Hagelsieb, G.; Orozco-Mosqueda Mdel, C.; Glick, B.R. Plant growth-promoting bacterial endophytes. Microbiol. Res. 2016, 183, 92-99. [CrossRef] 